New Zealand journal of industrial relations. 1986, 11. 161-175

\title{
The concentration of unemployment experience in spells of long duration: An analysis by age and sex
}

\author{
Peter Brosnan $\dagger$ and John Hicks*
}

\begin{abstract}
Estimates of the completed duration of unemployment are prepared by the generation life table method. It is found that the duration of unemployment spells increases with age. However younger workers have a higher probability of becoming unemployed. Thus their higher unemployment rate is due to more, but shorter spells of unemployment. The rise in the unemployment rate for males in recent years is primarily due to an increasing duration of unemployment. When we decompose unemployment by length of spell, we find that spells of 13 weeks and longer account for between 70 and 90 percent of all significant unemployment. These results call into question the theoretical base of Government's current employment policy.
\end{abstract}

\section{Introduction}

In the late 1960 s both Friedman (1968) and Phelps (1968) argued that there existed a "natural" rate of unemployment which could not be reduced in the long run through an expansion of demand without accelerating inflation. Further theoretical support for this proposition was provided by the development of job search theory which attributed unemployment to rational, voluntary decisions on the part of the unemployed? A familiar theme to this literature is that the average duration of completed spells of unemployment is quite short. In particular, conventional economic wisdom holds that it is the youth group (15-25 years) that will most clearly exhibit characteristics of this type (Trivedi and Baker, 1982). Whether or not this is a substantive belief is a matter of some consequence for the analysis of the New Zealand labour market, where the youth group accounts for over 50 percent of male unemployment and over 70 percent of female unemployment.

The average duration of unemployment is thus a most important statistic. As we have commented previously (Brosnan and Hicks, 1985), the number unemployed is the product of the number of people experiencing unemployment and the average length of their unemployment spells, but a given rate of unemployment can be consistent with different durations. For example an unemployment rate of 8.3 percent is consistent with each member of the labour force being unemployed for 1 month in 12 and with 1 person in 12 being unemployed continuously. But there are substantial problems in attempting to unravel unemployment data to obtain the average completed duration of unemployment $(\mathrm{ACD})$ for the $\mathrm{ACD}$ is not directly observable. Fowler (1968) developed a procedure for estimating ACD by modelling unemployment duration as a life table experience. This procedure was developed further and applied to New Zealand data by Brosnan and Hicks (1985). In this paper, we adopt and modify further the Brosnan-Hicks procedure in order to examine the duration of registered unemployment in New Zealand by age and sex. In general, for all groups, we find that unemployment is concentrated in spells of long duration (greater than 13 weeks), that ACD has risen over the period of our study, and that this rise has contributed significantly to the rise in unemployment.

†Senior Lecturer, Industrial Relations Centre, Victoria University of Wellington

*Principal Lecturer, Department of Banking and Finance, Chisholm Institute of Technology, Melbourne, Australia

The authors gratefully acknowledge the research assistance of Lee Chak Tin and Lynley Engelbrecht. The research was supported by Victoria University of Wellington Internal Research Grant No. 137/84. 
These findings have important implications for both theory and policy. At the theoretical level, our results call into question equilibrium views of labour markets that characterise the unemployment experience as a transitory phenomenon. At the policy level, the welfare significance of unemployment is highlighted, since the burden of unemployment is shown to be concentrated on a small number of workers who stay unemployed for a long period.

\section{Method}

Estimates of ACD were prepared by the generation life table method (Brosnan and Hicks, 1985). This method, when used by Paterson (1979 and 1980) for Australian data, was found to produce the most accurate estimates (Baker and Trivedi, 1982). In this method, a cohort of new entrants is traced through the unemployment register and their "life" on the register, together with their "mortality" of registration as they then quit job search or gain employment, can be depicted in the same way that human mortality is modelled in a life table. The principal advantage of this approach is that the various life table functions provide information on the proportion of unemployment spells finishing before specified durations, the escape rate between various duration categories and the expectation of further "life" on the register at each duration interval.

The data used were obtained from the Department of Labour's Monthly employment operations. These data are available from March 1981 onwards. To avoid monthly fluctuations, and those due to seasonal variations, we took the average of 12-monthly entry cohorts together. Thus we have life tables for the experience of those who become unemployed in the 3 periods of 12 months, March 1981 to February 1982, March 1982 to February 1983, and March 1983 to February 1984. Following Brosnan and Hicks (1985), we traced the cohort for 12 months beyond initial registration. Thus we required data up to February 1985.

Our method followed Brosnan and Hicks (1985) exactly in all except one respect. Although we have the numbers in each duration class by age group, we do not have the equivalent data for new entrants. Consequently our life table for each age group begins at duration 4 weeks rather than the usual 0 weeks. To make the tables for each age group comparable, they were adjusted to describe the experience of that particular age group out of the total new entrants. If we adjust the radix of the table for the total of all age groups to be 10000 , we can thus redefine the life table functions for each age group, with subscripts $u$ and $w$ and superscript $a$, as:

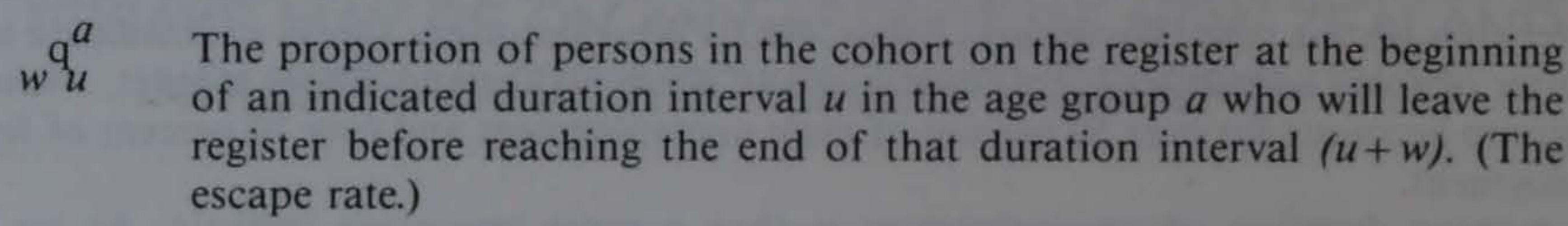

$1^{a} \quad$ The number of persons on the register in the age group $a$ at the beginning of the indicated duration interval $(u)$ out of the 10000 new registrants assumed as the radix of the table.

${ }_{w} \mathrm{~d}^{a} \quad$ The number of persons in the age group $a$ who leave the register within the indicated duration interval $(u$ to $u+w)$ out of the total number of new registrants assumed in the table.

${ }_{w} \mathrm{~L}^{a} \quad$ The number of person-weeks spent within the indicated duration interval $(u$ to $u+w$ ) on the register by the age group $a$ of the cohort of 10000 assumed new registrants.

$\mathrm{T}_{u}^{a} \quad$ The total number of person-weeks that would be spent on the register after the beginning of the duration interval by the age group $a$ of the cohort of 10000 assumed new registrants.

$\mathrm{e}^{a} \quad$ The average remaining time on the register (in weeks) for a person in the $w u \quad$ age group $a$ still on the register after the beginning of the indicated duration interval.

$\mathrm{V}^{a} u \quad$ The number of person-weeks spent in unemployment by persons, out of the cohort assumed, whose registration terminates in the interval $(u$ to $u+w)$ 
The functions and their relationship can be illustrated by Figure 1. The number of unemployed, $1_{u}^{a}$, is shown on the vertical axis and the duration $u$ is shown on the horizontal axis. Thus the curve $\mathrm{l}_{o}^{a}, u$ max will show the number unemployed at any given duration. If we take the interval 8 to 13 weeks as an example, we have the number leaving the register in that interval

$$
5_{8}^{a}=1_{8}^{a}-1_{13}^{a}
$$

The proportion leaving

$$
{ }_{5}^{\mathrm{q}_{8}^{a}}=\quad \begin{array}{r}
5_{8}^{\mathrm{d}_{8}^{a}} \\
\quad 1_{8}^{a}
\end{array}
$$

The number of person-weeks to be spent in unemployment beyond 8 weeks and less than 13 weeks is given by the areas $\mathrm{J}, \mathrm{K}$ and $\mathrm{M}$

$$
{ }_{58}^{L^{a}}=\mathrm{J}+\mathrm{K}+\mathrm{M}
$$

The total time spent in unemployment beyond the eighth week is

$$
\mathrm{T}_{8}^{a}=\mathrm{J}+\mathrm{K}+\mathrm{M}+\mathrm{N}+\mathrm{P}+\mathrm{R}
$$

The average time spent in unemployment by those still unemployed at the eighth week is

$$
\mathrm{e}_{8}^{a}=\begin{gathered}
\mathrm{T}_{8}^{a} \\
\mathrm{l}_{8}^{a}
\end{gathered}=\mathrm{J}+\mathrm{K}+\mathrm{M}+\mathrm{N}+\mathrm{P}+\mathrm{R}
$$

Finally the number of person-weeks spent in unemployment by those who leave the register between 8 and 13 weeks is the sum of the areas $C, G$ and J, i.e.

$$
{ }_{5} \mathrm{v}_{8}^{a}=\mathrm{C}+\mathrm{G}+\mathrm{J}
$$

The life tables described and analysed in Brosnan and Hicks (1985) were for all age groups combined. The relation between those and the tables reported here is quite straightforward. We omit the superscript to designate the total of all age groups and we have:

$$
\begin{aligned}
1_{u} & =\sum_{a} 1_{u}^{a} \\
1_{0} & =\sum_{a} 1_{0}^{a}=10000 \\
\mathrm{~d}_{w} & =\sum_{a} \mathrm{~d}^{a} u^{\prime} \\
w^{\mathrm{L} u} & =\sum_{a} \mathrm{~L}^{a} u^{a} \\
\mathrm{~T} & =\sum_{a} \mathrm{~T}_{u}^{a} \\
u & \text { and } \\
\mathrm{V} u & =\sum \mathrm{V}^{a} \\
w u &
\end{aligned}
$$




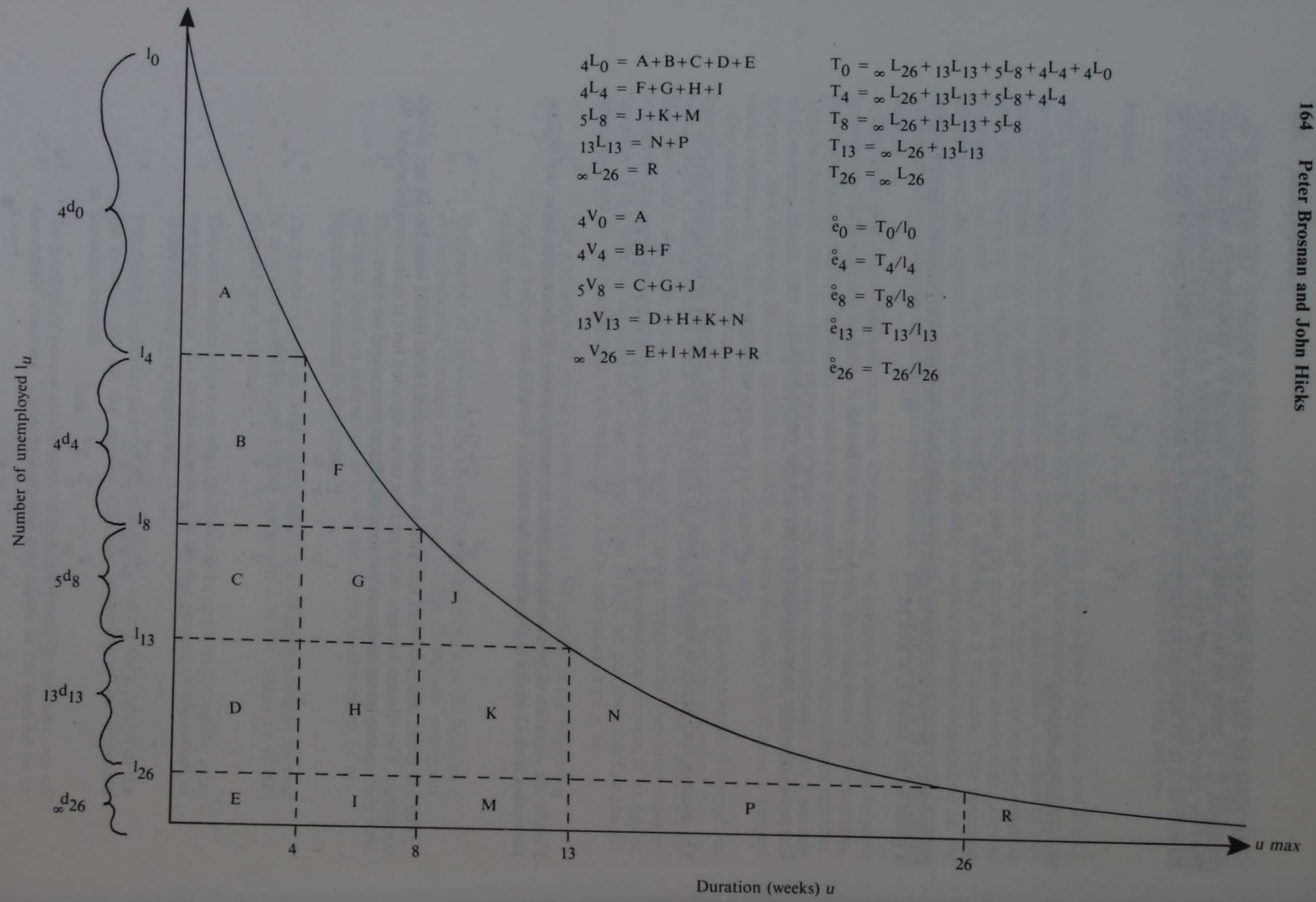




\section{Change in method and the interpretation of ACD}

The foregoing modification in methodology, necessitated by the absence of data on inflows into unemployment by age group, means that we are unable to calculate ACD by age in a manner directly comparable with the results reported in Brosnan and Hicks (1985). In that paper, the key variable was the average completed duration of unemployment for all persons entering the register (henceforth $\mathrm{ACD}^{a}=\mathrm{e}_{0}^{a}$ ). In this paper, the analogous, but clearly not identical variable is the average completed duration of unemployment for all persons entering the register and who will experience more than 4 weeks on the register $\left(\mathrm{ACD}_{4}^{a}=\mathrm{e}_{4}^{a}+4\right)$. The distinction between $\mathrm{ACD}_{0}^{\alpha}$ and $\mathrm{ACD}_{4}^{a}$ may be clarified by reference to Figure 1.

$$
\mathrm{ACD}_{0}=\mathrm{e}_{0}^{a}=(\mathrm{A}+\mathrm{B}+\mathrm{C}+\mathrm{D}+\mathrm{E}+\mathrm{F}+\mathrm{G}+\mathrm{H}+\mathrm{I}+\mathrm{J}+\mathrm{K}+\mathrm{M}+\mathrm{N}+\mathrm{P}+\mathrm{R}) / \mathrm{l}_{0}^{a}
$$

On the other hand

$$
\mathrm{ACD}_{4}=\mathrm{e}_{4}^{a}+4=(\mathrm{F}+\mathrm{G}+\mathrm{H}+\mathrm{I}+\mathrm{J}+\mathrm{K}+\mathrm{M}+\mathrm{N}+\mathrm{P}+\mathrm{R}) / \mathrm{l}_{4}^{a}+4
$$

Where $1_{4}^{a}$ is the number of the original registrants surviving to experience 4 complete weeks of unemployment. $(\mathrm{B}+\mathrm{C}+\mathrm{D}+\mathrm{E})$ is the group's $\left(\mathrm{l}_{4}^{a}\right)$ total unemployment up to 4 weeks. $\mathrm{ACD}_{4}^{a}$ therefore excludes the unemployment experience of the inflow group during the first 4 weeks (the area $\mathrm{A}$ in Figure 1). In our analysis reported below, after having estimated a value for $\mathrm{e}_{4}^{a}$, the average remaining time on the register (in weeks), we add 4 (weeks) in order to obtain $\mathrm{ACD}_{4}^{a}$.

Readers are warned of the difficulty of interpreting either $\mathrm{ACD}_{0}^{a}$ or $\mathrm{ACD}_{4}^{a}$ as an estimate of the average completed duration of a spell of unemployment. Both measures, for the particular groups concerned, are measures of average time spent on the register of unemployed. This differs from the former concept because; (a) not all of the unemployed actually enter the register, (b) only part of the time spent in unemployment may be recorded on the register because the unemployed either fail to register their unemployed status immediately and/or allow their registration to lapse before they have left unemployment, or (c) persons may leave unemployment but not be removed immediately from the register. (A detailed analysis of the relationship between registered unemployment and "true" unemployment is provided in Hicks (1985).)

While ideally we would prefer to have been able to calculate $\mathrm{ACD}_{0}^{a}$, the alternative $\mathrm{ACD}_{4}^{a}$ is still a useful measure of duration on the register. Apart from the group who, though remaining unemployed, allows their registration to lapse, departures from the register will be comprised of (a) movements out of the work force and (b) movements into employment. For those who depart the register prior to 4 weeks registration because of (a) or (b), the unemployment experience can be regarded as less severe. Persons with a short spell of recorded "job search" probably have a weak attachment to the work force, while those who obtain jobs quickly and easily have clearly not been confronted with any major impediment to employment. Consequently, we interpret our measure, $\mathrm{ACD}_{4}^{a}$, as the average completed duration of spells on the register for persons in group $a$ entering the register who will experience a "significant" spell of recorded unemployment. (Where "significant" unemployment $\left(\mathrm{U}^{\mathrm{S}}\right)$ is defined as a spell of recorded unemployment that exceeds 4 weeks duration. $)^{2}$

\section{Results}

Our empirical work resulted in the construction of 48 life tables. Obviously, considerations of space do not permit us to reprint this information here. An indication of the types of life tables constructed are presented as Figures 2 and 3 . Figure 2 is similar to the tables presented in Brosnan and Hicks (1985, p. 125-126). It shows the unemployment experience of 10000 males who become unemployed during 1981-1982 as they enter the register and eventually leave it again. Figure 3 is one of the subsets of Table 1 and shows the experience from the fourth week of registration onwards of the group of males aged 15-19. We have similar life tables for each of the 7 age groups: school leavers, 15-19, 20-24, 25-29, 30-39, 40-59 and 60 plus. Having tables for both sexes for each year we have 48 tables in total. 
Figure 2: Duration Table: All Males: 1981-82

\begin{tabular}{|c|c|c|c|c|c|c|c|c|}
\hline $\begin{array}{l}\text { Duration } \\
\text { interval }\end{array}$ & Of $10000 n$ & registrants & $\begin{array}{l}\text { Probability that a } \\
\text { at the beginning of }\end{array}$ & $\begin{array}{l}\text { son on the register } \\
\text { e duration interval }\end{array}$ & & Weeks spent & & $\begin{array}{l}\text { Expectation } \\
\text { of registration }\end{array}$ \\
\hline $\begin{array}{l}\text { Period of } \\
\text { registration } \\
\text { between two } \\
\text { exact durations } \\
\text { stated in } \\
\text { weeks }\end{array}$ & $\begin{array}{l}\text { Number on } \\
\text { the register } \\
\text { at beginning of } \\
\text { duration interval }\end{array}$ & $\begin{array}{l}\text { Number leaving } \\
\text { register during } \\
\text { duration interval }\end{array}$ & $\begin{array}{l}\text { Leaves } \\
\text { the register } \\
\text { during interval }\end{array}$ & $\begin{array}{l}\text { Remains on the } \\
\text { register at end } \\
\text { of interval }\end{array}$ & $\begin{array}{l}\text { In } \\
\text { the duration } \\
\text { interval }\end{array}$ & $\begin{array}{l}\text { In this and } \\
\text { all subsequent } \\
\text { duration intervals }\end{array}$ & $\begin{array}{l}\text { On register by } \\
\text { those leaving } \\
\text { register during } \\
\text { duration interval }\end{array}$ & $\begin{array}{l}\text { Average number } \\
\text { of weeks remaining } \\
\text { at beginning of } \\
\text { duration interval }\end{array}$ \\
\hline$u$ to $u+w$ & $1_{u}$ & $w^{\mathrm{d}_{u}}$ & $w^{q_{u}}$ & $w^{\mathrm{p}_{u}}$ & $\mathrm{~L}_{u}$ & $\mathrm{~T}_{u}$ & ${ }_{w} \mathrm{~V}_{u}$ & $\stackrel{\circ}{e} u_{u}$ \\
\hline $\begin{array}{c}0-4 \\
4-8 \\
8-13 \\
13-26 \\
26+\end{array}$ & $\begin{array}{rl}10 & 000 \\
5 & 005 \\
3 & 165 \\
1 & 858 \\
& 813\end{array}$ & $\begin{array}{r}4995 \\
1840 \\
1307 \\
1045 \\
\quad 813\end{array}$ & $\begin{array}{l}0.50 \\
0.37 \\
0.41 \\
0.56 \\
1.00\end{array}$ & $\begin{array}{l}0.50 \\
0.63 \\
0.59 \\
0.44 \\
0.00\end{array}$ & 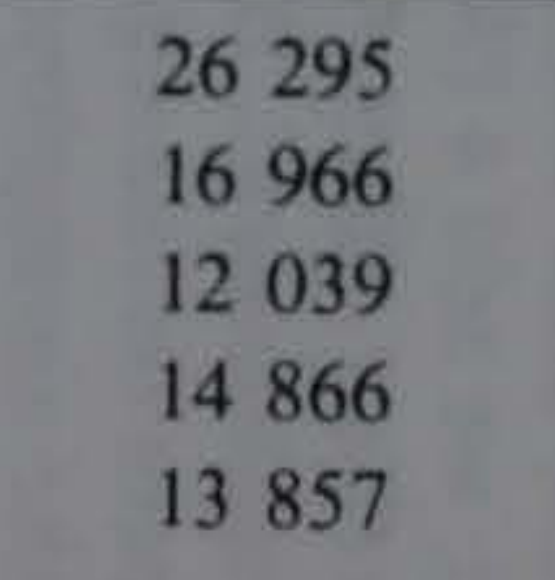 & $\begin{array}{ll}84 & 023 \\
57 & 728 \\
40 & 762 \\
28 & 723 \\
13 & 857\end{array}$ & $\begin{array}{r}6275 \\
11666 \\
13205 \\
17882 \\
34995\end{array}$ & $\begin{array}{r}8.40 \\
11.53 \\
12.87 \\
15.45 \\
17.04\end{array}$ \\
\hline
\end{tabular}

Source: Computed from Department of Labour (various) 
Figure 3: Duration Table: Males: 15-19: 1981-82

\begin{tabular}{|c|c|c|c|c|c|c|c|c|}
\hline \multirow{2}{*}{\begin{tabular}{|c|}
$\begin{array}{c}\text { Duration } \\
\text { interval }\end{array}$ \\
$\begin{array}{c}\text { Period of } \\
\text { registration } \\
\text { between two } \\
\text { exact durations } \\
\text { stated in } \\
\text { weeks }\end{array}$
\end{tabular}} & \multicolumn{2}{|c|}{ Of 10000 new registrants } & \multicolumn{2}{|c|}{$\begin{array}{l}\text { Probability that a person on the register } \\
\text { at the beginning of the duration interval }\end{array}$} & \multicolumn{3}{|c|}{ Weeks spent } & \multirow{2}{*}{\begin{tabular}{|c|c}
$\begin{array}{c}\text { Expectation } \\
\text { of registration }\end{array}$ \\
$\begin{array}{c}\text { Average number } \\
\text { of weeks remaining } \\
\text { at beginning of } \\
\text { duration interval }\end{array}$ \\
\end{tabular}} \\
\hline & $\begin{array}{l}\text { Number on } \\
\text { the register } \\
\text { at beginning of } \\
\text { duration interval }\end{array}$ & $\begin{array}{l}\text { Number leaving } \\
\text { register during } \\
\text { duration interval }\end{array}$ & $\begin{array}{l}\text { Leaves } \\
\text { the register } \\
\text { during interval }\end{array}$ & $\begin{array}{l}\text { Remains on the } \\
\text { register at end } \\
\text { of interval }\end{array}$ & $\begin{array}{l}\text { In } \\
\text { the duration } \\
\text { interval }\end{array}$ & $\begin{array}{l}\text { In this and } \\
\text { all subsequent } \\
\text { duration intervals }\end{array}$ & $\begin{array}{l}\text { On register by } \\
\text { those leaving } \\
\text { register during } \\
\text { duration interval }\end{array}$ & \\
\hline$u$ to $u+w$ & $1_{u}$ & ${ }^{\mathrm{d} \mathrm{d}_{u}}$ & $w^{q_{u}}$ & ${ }_{w} \mathrm{p}_{u}$ & $\mathrm{~L}_{u}$ & $\mathrm{~T}_{u}$ & ${ }_{w} \mathrm{~V}_{u}$ & $\stackrel{\circ}{\mathrm{e}}_{u}$ \\
\hline $\begin{array}{c}4-8 \\
8-13 \\
13-26 \\
26+\end{array}$ & $\begin{array}{r}1311 \\
759 \\
399 \\
146\end{array}$ & $\begin{array}{l}552 \\
360 \\
253 \\
146\end{array}$ & $\begin{array}{l}0.42 \\
0.47 \\
0.63 \\
1.00\end{array}$ & $\begin{array}{l}0.58 \\
0.53 \\
0.37 \\
0.00\end{array}$ & $\begin{array}{l}4322 \\
2723 \\
2883 \\
1595\end{array}$ & $\begin{array}{r}11523 \\
7201 \\
4478 \\
1595\end{array}$ & $\begin{array}{l}3494 \\
3607 \\
4274 \\
5391\end{array}$ & $\begin{array}{r}8.79 \\
9.49 \\
11.22 \\
10.92\end{array}$ \\
\hline
\end{tabular}

Source: Computed from Department of Labour (various) 
Table 1: Values of $\stackrel{\circ}{\mathrm{e}}_{u}^{a}$ and $\mathrm{ACD}_{4}^{a}$ (weeks)

\begin{tabular}{|c|c|c|c|c|c|c|c|c|c|c|c|c|c|c|c|}
\hline \multirow[t]{2}{*}{ Group } & \multicolumn{3}{|c|}{$\mathrm{e}_{4}^{a}$ (4 weeks) } & \multicolumn{3}{|c|}{$\stackrel{\circ}{\mathrm{e}}_{8}^{a}$ (8 weeks) } & \multicolumn{3}{|c|}{$\stackrel{\circ}{1}_{13}^{a}$ (13 weeks) } & \multicolumn{3}{|c|}{$\stackrel{\circ}{e}_{26}^{a}$ (26 weeks) } & \multicolumn{3}{|c|}{$\mathrm{ACD}_{4}^{a}$ (weeks) } \\
\hline & $\begin{array}{r}1981- \\
82\end{array}$ & $\begin{array}{r}1982- \\
83\end{array}$ & $\begin{array}{r}1983- \\
84\end{array}$ & $\begin{array}{r}1981- \\
82\end{array}$ & $\begin{array}{r}1982- \\
83\end{array}$ & $\begin{array}{r}1983- \\
84\end{array}$ & $\begin{array}{r}1981- \\
82\end{array}$ & $\begin{array}{r}1982- \\
83\end{array}$ & $\begin{array}{r}1983- \\
84 \\
\end{array}$ & $\begin{array}{r}1981- \\
82 \\
\end{array}$ & $\begin{array}{r}1982- \\
83\end{array}$ & $\begin{array}{r}1983- \\
84\end{array}$ & $\begin{array}{r}1981- \\
82 \\
\end{array}$ & $\begin{array}{r}1982- \\
83\end{array}$ & $\begin{array}{r}1983- \\
84 \\
\end{array}$ \\
\hline \multicolumn{16}{|l|}{$\begin{array}{l}\text { Males } \\
\text { School }\end{array}$} \\
\hline Leavers & 9.15 & 10.40 & 11.04 & 9.93 & 11.38 & 11.08 & 11.67 & 13.63 & 11.98 & 12.71 & 12.71 & 11.27 & 13.15 & 14.40 & 15.04 \\
\hline $15-19$ yrs & 8.79 & 10.90 & 11.45 & 9.49 & 11.93 & 11.38 & 11.22 & 13.92 & 12.27 & 10.92 & 12.84 & 10.20 & 12.79 & 14.90 & 15.45 \\
\hline $20-24$ yrs & 10.25 & 12.24 & 13.05 & 11.19 & 13.23 & 13.01 & 13.34 & 15.37 & 14.11 & 13.59 & 15.26 & 12.04 & 14.25 & 16.24 & 17.05 \\
\hline $25-29$ yrs & 12.26 & 14.03 & 14.77 & 13.44 & 15.19 & 14.79 & 15.57 & 17.44 & 15.98 & 16.74 & 17.51 & 14.16 & 16.26 & 18.03 & 18.77 \\
\hline $30-39$ yrs & 14.12 & 15.58 & 16.37 & 15.66 & 17.08 & 16.46 & 18.28 & 19.71 & 17.89 & 19.70 & 19.78 & 16.27 & 18.12 & 19.58 & 20.37 \\
\hline $40-59$ yrs & 18.32 & 19.21 & 19.40 & 20.15 & 20.96 & 19.99 & 23.32 & 23.99 & 21.94 & 25.96 & 24.98 & 20.80 & 22.32 & 23.21 & 23.40 \\
\hline $60+y r s$ & 17.83 & 18.22 & 20.50 & 19.85 & 20.23 & 23.30 & 23.00 & 23.22 & 27.43 & 25.20 & 24.80 & 24.20 & 21.83 & 22.22 & 24.50 \\
\hline Total & 11.53 & 13.37 & 14.00 & 12.87 & 14.70 & 14.80 & 15.45 & 17.18 & 15.58 & 17.04 & 17.38 & 14.20 & 15.53 & 17.37 & 18.00 \\
\hline \multirow{2}{*}{\multicolumn{16}{|c|}{$\begin{array}{l}\text { Females } \\
\text { School } \\
\text { Leavers }\end{array}$}} \\
\hline & & & & & & & & & & & & & & & \\
\hline Leavers & 11.84 & 12.70 & 12.75 & 12.56 & 13.59 & 12.68 & 14.31 & 15.44 & 13.11 & 13.90 & 13.46 & 11.34 & 15.84 & 16.70 & 16.75 \\
\hline $15-19$ yrs & 11.21 & 12.79 & 12.84 & 12.00 & 13.55 & 12.85 & 13.83 & 15.28 & 13.78 & 13.06 & 14.55 & 11.86 & 15.21 & 16.79 & 16.84 \\
\hline $20-24$ yrs & 11.49 & 12.37 & 12.99 & 12.71 & 13.46 & 13.09 & 15.11 & 15.80 & 14.38 & 15.29 & 16.45 & 12.86 & 15.49 & 16.37 & 16.99 \\
\hline $25-29$ yrs & 12.14 & 12.87 & 13.49 & 13.72 & 14.38 & 14.07 & 17.01 & 17.56 & 16.01 & 19.60 & 19.66 & 16.08 & 16.14 & 16.87 & 17.49 \\
\hline $30-39$ yrs & 13.24 & 13.70 & 14.63 & 15.50 & 15.61 & 15.62 & 19.35 & 18.88 & 18.03 & 21.89 & 20.88 & 18.56 & 17.24 & 17.70 & 18.63 \\
\hline $40-59$ yrs & 18.11 & 18.75 & 19.87 & 21.55 & 21.58 & 21.50 & 26.01 & 26.09 & 24.64 & 28.13 & 27.37 & 25.85 & 22.11 & 22.75 & 23.87 \\
\hline $60+y r s$ & 14.28 & 12.00 & 18.20 & 19.50 & 13.00 & 25.00 & 31.00 & 20.00 & 31.00 & 40.00 & 25.00 & 43.00 & 18.28 & 16.00 & 22.20 \\
\hline Total & 12.05 & 13.16 & 13.58 & 13.31 & 14.34 & 13.88 & 15.83 & 16.75 & 15.29 & 16.43 & 17.01 & 14.44 & 16.05 & 17.16 & 17.58 \\
\hline
\end{tabular}

Source: Computed from Department of Labour (various) 
The result which interests us the most is the values obtained for $\stackrel{\mathrm{e}}{\mathrm{u}}_{\mathrm{u}}^{a}$. In terms of Figure 1, values such as $\dot{e}_{13}=(\mathrm{N}+\mathrm{P}+\mathrm{R}) / 1_{13}^{a}$ and corresponding values for other durations. These are reported in Table 1. Brosnan and Hicks (1985) found a marked tendency for $\dot{\mathrm{e}}_{\mathrm{u}}$ to increase with time spent on the register. (That is for the curve $1_{0}^{a}, u \max$ to become flatter with increasing values of $u$.) A similar pattern is also apparent in these data. The only exception to this occurs for the 1983-84 cohort - those entering unemployment between March 1983 and February 1984. For young (up to 25 years) females, the expected duration of further unemployment is less at 26 weeks than at 4,8 and 13 weeks. This reversal is also found for males in all age groups up to and including 30-39 years. The Department of Labour began to restrict access to the Project Employment Programme (PEP) to those unemployed 26 weeks or more in 1984. Quite clearly this policy bit heavily into the number of long-term registered unemployed. Although the drop in $\stackrel{\circ}{2}_{26}$ values between 1981-2 and 1983-4 suggests all groups, other than women 60 years and older, appear to have benefited from these schemes, the policy appears to have been applied more readily to young women and young and prime-aged (25 to 39 years) males than to prime-age women and the elderly. In addition, the qualifying period adopted seems to have been unnecessarily restrictive, as it failed to result in a fall in any $\mathrm{ACD}_{4}^{a}$ value (to which we turn presently).

Values for $\mathrm{ACD}_{4}^{a}$ are recorded in the last 3 columns of Table 1. In general, all groups exhibit increasing duration of unemployment over the period. Overseas studies have generally concluded that duration of unemployment is directly related to age (Bowers and Harkness, 1979; Paterson, 1980) and the New Zealand data supports this view. For both sexes, younger workers tend to experience shorter spells of unemployment than do older workers. This tendency is, however, more marked for males than for females who experience less diversity in the distribution of their duration data. For example, in 1983-4, the 4 youngest female groups, exhibited a range in $\mathrm{ACD}_{4}^{q}$ from 16.75 weeks (Female school leavers) to 18.63 weeks (Females 30-39 years). On the other hand, the corresponding male groups ranged from 15.04 weeks to 20.58 weeks. While both sexes experience a reversal of the trend of increasing $\mathrm{ACD}_{4}^{a}$ at 60 years and older, it is more pronounced for females. This probably indicates a greater readiness by unemployed older women to move into retirement compared with men of the same age. A comparison of duration by sex, for each age group, reveals that school leavers and teenage males generally experience shorter spells of unemployment than females of the same age. However, for prime-age and older workers, the situation is reversed.

It is commonly observed ${ }^{3}$ that duration increases with the level of unemployment. Comparing our values of $\mathrm{ACD}_{4}^{a}$ (in Table 1) with the corresponding unemployment rates (Ur) and "significant" unemployment rates $\left(\mathrm{Ur}^{s a}\right)^{4}$ in Table 2, we see that this finding is supported by our data. However, a similar relationship does not hold across groups at a given point in time. Indeed, the opposite is the case: the younger age groups, which have relatively higher unemployment rates, tend to exhibit relatively shorter duration; and the older age groups with relatively low unemployment rates tend to exhibit relatively longer duration. The explanation of this phenomenon is readily discerned if we recall the analysis of the relationship between inflows into unemployment and average completed duration, discussed in the preceding section. In a stationary state, ${ }^{5}$ the unemployment experience of the inflow $\left(\mathrm{l}_{\mathrm{o}}\right)$ will equal the stock of unemployed (UE). Thus, the relationship between the unemployment rate (Ur), the proportion of the labour force becoming unemployed each week (Ir) and the average completed duration in weeks $\left(\mathrm{ACD}_{0}^{a}\right)$ can be given by

$$
\mathrm{Ur}=\mathrm{Ir} . \mathrm{ACD}_{0}
$$

3 See, for example, Trivedi and Baker (1982) and Brosnan and Hicks (1985).

4 The "significant" unemployment rate is the number of unemployed who have experienced a spell in excess of 4 weeks divided by the labour force.

5 In terms of Figure 2, a stationary state is defined as one in which the total stock, and the numbers in each duration group, are not changing because the flows of people leaving the register are exactly balanced by the flow of new registrations

$\mathrm{Ur}_{\mathrm{r}}=(\mathrm{F}+\mathrm{G}+\mathrm{H}+\mathrm{I}+\mathrm{J}+\mathrm{K}+\mathrm{M}+\mathrm{N}+\mathrm{P}+\mathrm{R}) /$ labour force aged $a$ and by the lengthening duration of unemployment of those who remain on the register. 
Table 2: Unemployment rates by age and sexa (Percent)

Age and Sex Groups

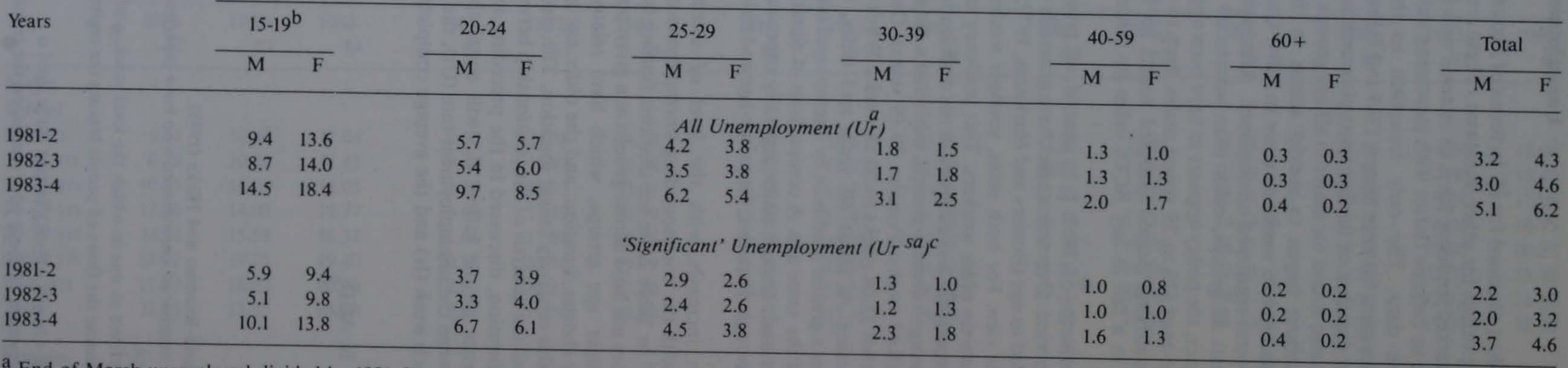

a End of March unemployed divided by 1981 Census Labour Force.

$\mathrm{b}$ Including school leavers

${ }^{c}$ Unemployment spells in excess of 4 weeks current duration.

Source: Computed from Department of Labour (various) and Department of Statistics (1981) 
Over time, Ir and $\mathrm{ACD}_{0}$ can normally be expected to move together. However, at any point in time, variations in $\mathrm{I}_{r}^{a}$ between groups will co-exist with variations in $\mathrm{ACD}_{0}^{a}$. The observation that the higher unemployment rates for workers under 30 are accompanied by relatively shorter spells of unemployment than experienced by workers over 30 , implies that workers in the younger age groups have a greater probability of becoming unemployed. That is, the inflow rate into unemployment for the younger age groups is not only higher than that for older age groups, it also more than offsets the impact on the unemployment rate of the shorter duration of spells experienced by the younger groups. ${ }^{6}$

The relationship expressed by (1), provides a basis for decomposing the observed changes in unemployment over time into components attributable to changes in inflow and changes in duration, i.e.;

$$
\mathrm{dUr}=\mathrm{dIr} . \mathrm{ACD}_{0}+\mathrm{dACD} \mathrm{Ir}_{0}
$$

which can be approximated in discrete time by

$$
\begin{gathered}
U r_{t}-U_{t-1}=\overline{A C D}_{0}\left(\operatorname{Ir}_{t}-I_{t-1}\right)+\overline{I r}\left(A_{C D} D_{0 t}-A C D_{0 t-1}\right) \\
\text { where } \overline{A C D}_{0}=1 / 2\left(A C D_{0 t}+A C D_{0 t-1}\right) \text { and } \overline{I r}=1 / 2\left(I r_{t}+I r_{t-1}\right)
\end{gathered}
$$

Given values for $\mathrm{ACD}_{0}$ and $\mathrm{Ur}$, we can proceed to calculate the relative contribution of changes in duration and inflows to changes in unemployment. Unfortunately, the data available only permits this calculation to be made for total males and females. In the first part of Table 3 , we report our estimates of the percentage contribution to the change in the unemployment rate of a change in $\mathrm{ACD}_{0}\left(\stackrel{\mathrm{e}}{0}_{0}\right)$. This rise in New Zealand's unemployment rates, which have culminated in the current historically high levels of unemployment, began in 1977. The first row in Table 3, which is based on data from Brosnan and Hicks (1985), indicates that approximately 36 percent of the rise in male unemployment and 34 percent of the rise in female unemployment, between 1977 and 1983, can be attributed to the increasing duration of unemployment spells. For the period covered by the present study, 1981-1984, increasing duration has accounted for a slightly higher proportion of the increase in male unemployment, but a remarkably smaller proportion of the increasing female unemployment. Thus, for males, increasing unemployment duration seems to have become a more important determinant of rising unemployment levels, whilst for females, its importance has almost certainly declined.

The remaining data in Table 3, refers to the contribution of increasing duration to rises in "significant" unemployment rates by age and sex. Analogous with our previous analysis, the stock of "significant" unemployment is given by the area $(F+G+H+I+J+K+M+N+P+R)$ in Figure 1. The inflow rate into "significant" unemployment is given by the ratio of the numbers entering the 4-8 weeks category of the register per week and the labour force $\left(\operatorname{Ir}_{4}^{a}\right.$; the expected time remaining on the register is given by $\left(\mathrm{e}_{4}^{a}\right.$. Thus, in terms of equation (1),

$$
\stackrel{\mathrm{s} a}{\mathrm{Ur}}=\stackrel{a}{\mathrm{Ir}} \stackrel{a}{ } \stackrel{\stackrel{\circ}{\mathrm{e}} 4}{a}
$$

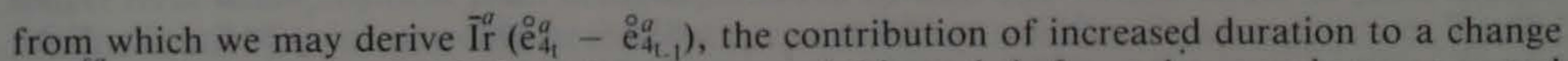
in Ur. In constructing Table 3, we have computed this statistic for each age and sex group and expressed it as a percentage of the change in the "significant" unemployment rate for the group. From our reported results, it is again apparent that over the period 1981-2 to 1983-4, increasing duration contributed more to the rise in "significant" unemployment rates for males than for females. This holds true across all of the age groups except 40-59. Especially interesting in this section of the table, is the fact that, over the groups observed; the level of contribution of changes in $\mathrm{e}_{4}^{a}$ to increased unemployment is inversely related to the level of ${ }^{\circ}{ }_{4}^{g}$. This implies that for groups with relatively low $\mathrm{ACD}_{4}^{a}$ 's, increasing duration has been a more important determinant of rising $\mathrm{Ur}_{\mathrm{r}}^{s a}$ than for groups with higher $\mathrm{ACD}_{4}^{a} \mathrm{~s}$. Thus, while conventional wisdom, apparently correctly, places emphasis on the inflows as the dominant cause of the higher level of unemployment amongst young workers, increasing duration may be a more important cause of changes in unemployment level for these groups than it is for older workers. 
Table 3: Contribution of changes in $\mathrm{e}_{0}$ to changes in the unemployment rate (Ur) and contribution of changes in $\stackrel{\circ}{4}_{4}^{a}$ to changes in the "significant" unemployment rate $\left(\mathrm{Ur}_{\mathrm{r}}^{\mathrm{sa}}\right.$ ).

\begin{tabular}{lcccc} 
Group and Period & & \multicolumn{2}{c}{$\begin{array}{c}\text { Percentage } \\
\text { Males }\end{array}$} & $\begin{array}{c}\text { Contribution } \\
\text { Females }\end{array}$ \\
\hline $\begin{array}{l}\text { Total } \\
\text { Total }\end{array}$ & $(\mathrm{Ur})$ & $1977-1983$ & $35.7^{\mathrm{a}}$ & $34.0^{\mathrm{b}}$ \\
& & $1981-2-1983-4$ & $37.9^{\mathrm{c}}$ & $16.3^{\mathrm{d}}$ \\
$15-19 \mathrm{yrs}$ & $\left(\mathrm{Ur}_{\mathrm{r}}^{\mathrm{s} a}\right)$ & $1981-2-1983-4$ & 42.1 & 27.3 \\
$20-24 \mathrm{yrs}$ & & $1981-2-1983-4$ & 40.7 & 27.7 \\
$25-29 \mathrm{yrs}$ & $1981-2-1983-4$ & 42.5 & 28.3 \\
$\begin{array}{l}30-39 \mathrm{yrs} \\
40-59 \mathrm{yrs}\end{array}$ & $1981-2-1983-4$ & 26.0 & 17.5 \\
$60+\mathrm{yrs}$ & $1981-2-1983-4$ & 13.3 & 22.0 \\
Total & $1981-2-1983-4$ & 15.0 & $-\mathrm{e}$ \\
\hline & $1981-2-1983-4$ & 37.5 & 28.1 \\
\hline
\end{tabular}

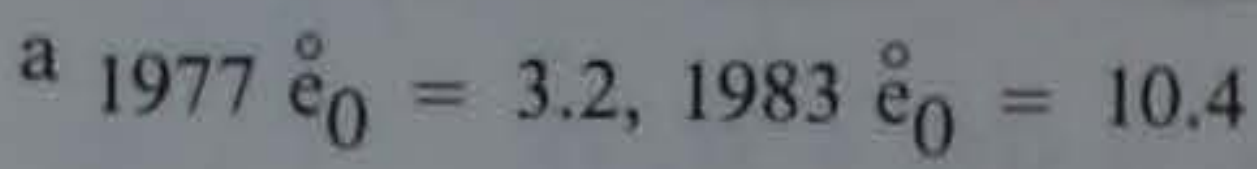

b $1977 \stackrel{\circ}{0}_{0}=4.21983 \stackrel{\circ}{0}_{0}=9.4$

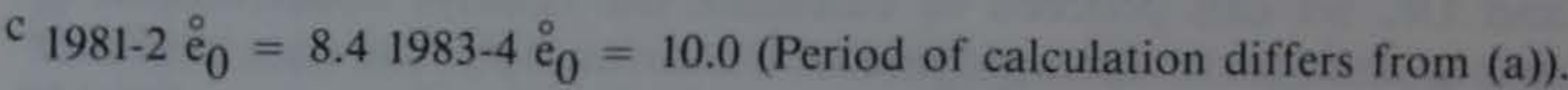

d $1981-2{\stackrel{\circ}{e_{0}}}_{0}=8.51983-4 \stackrel{\circ}{\circ}_{0}=9.0$ (Period of calculation differs from (b)).

Increase in duration offsets a decline in inflows exactly.

Source: Calculated from data reported in Brosnan and Hicks (1985) and Tables 1 and 2.

Values for $\stackrel{\circ}{0}_{0}$ reported in notes $\mathrm{c}$ and d were generated from the current study.

Table 5: The contribution of spells 13 weeks and longer to significant unemployment $\left(\infty X_{13}^{a}\right)$ and to total unemployment $\left(\infty \mathrm{Y}_{13}^{a}\right)$ : percent

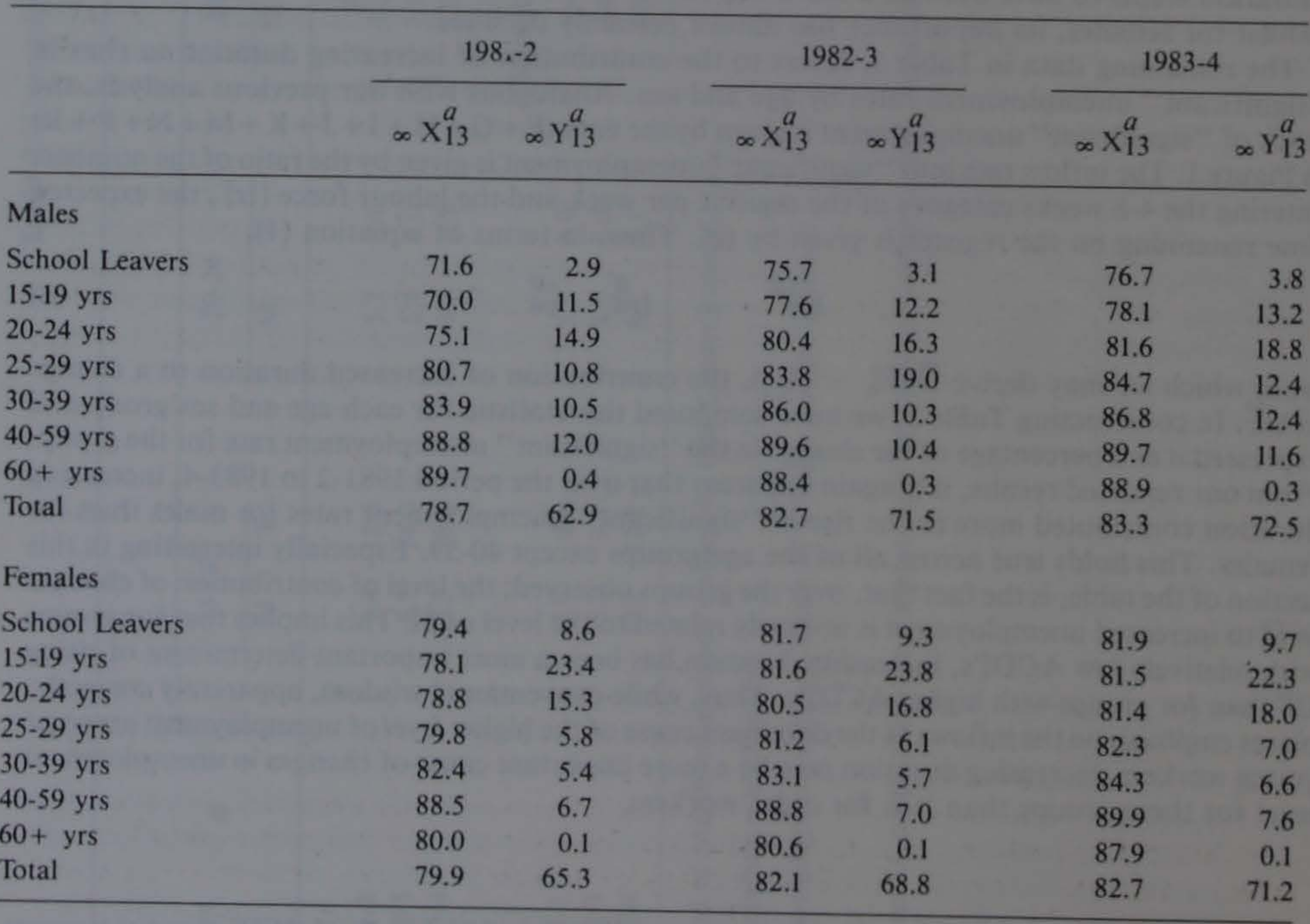

Source: Computed from Department of Labour (various) 
To this point, we have observed that the average completed duration of a spell of unemployment is quite long, that it has been increasing and that this rise has contributed significantly to increased unemployment. Such a scenario is not supportive of the search theorists case outlined in our introduction. Workers are clearly finding it more difficult to obtain jobs as the average spell of unemployment becomes something less than "transitory".

Indeed, if we focus upon the contribution of spells of varying length to (a) total spells $\left(w \mathrm{~d}_{u}^{a} / 1_{0}^{a}\right.$ $\times 100)\left(\mathrm{e} . \mathrm{g}\right.$. in terms of Figure 1, spells of length $5-8$ weeks are $\left(s \mathrm{~d}_{8}^{a} / 1_{0}^{a} \times 100\right)$ percent of all spells) and (b) total unemployment $\left(\frac{\mathrm{w}_{\mathrm{u}}}{\mathrm{T}_{0}} \times 100\right)(\mathrm{e} . \mathrm{g}$. in terms of Figure 1, spells of 8-13 weeks account for $\left(G V_{8}^{a} / T_{0} \times 100\right)$ percent of all unemployment i.e. $(C+G+J) /(A+B+C+D+$ $\mathrm{E}+\mathrm{F}+\mathrm{G}+\mathrm{H}+\mathrm{I}+\mathrm{J}+\mathrm{K}+\mathrm{M}+\mathrm{N}+\mathrm{P}+\mathrm{R})$ ), both reported in Table 4, it becomes obvious that, throughout the period of our study, unemployment spells of a transitory nature have not been a major contributor to the level of unemployment. While close to half of all unemployment spells end within 4 weeks, such spells never account for more than 7.5 percent of male unemployment and 6.3 percent of female unemployment. On the other hand, long spells (of 13 weeks or longer) generally make up less than one quarter of all spells, yet generate more than 60 percent of male and female unemployment. Equally apparent in the table, is the increasing importance of longer spells - both in terms of their contribution to total spells and their contribution to unemployment. The inescapable conclusion is that although a majority of spells are of short duration, most unemployment is explained by long spells.

Once again, because of the absence of data on inflows by age group, we are unable to replicate this analysis precisely by age. We can, however, calculate the contribution of spells of varying length to "significant" unemployment within the groups

$$
\left[{ }_{w} \mathrm{X}_{u}^{a}=\frac{{ }_{w} \mathrm{~V}_{u}^{a}-4\left({ }_{w} \mathrm{~d}_{u}^{a}\right)}{\mathrm{T}_{4}^{a}} \times 100\right], \text { and the }
$$

contribution of spells of varying length for each group to total unemployment

$$
\left[w \mathrm{Y}_{u}^{a}=\frac{{ }_{w} \mathrm{~V}_{u}^{a}}{\mathrm{~T}_{0}} \times 100\right]
$$

Table 5 reports the results of these computations for spells in excess of 13 weeks $\infty \mathrm{X}_{13}^{a}$ and $\infty \mathrm{Y}_{13}^{a}$.

For each group, the contribution of longer spells to the group's "significant" unemployment is high and rising over the period of our enquiry. In no case do spells in excess of 13 weeks account for less than 70 percent of "significant" unemployment. A number of features with respect to the contribution of longer spells to "significant" unemployment are apparent. First, it generally increases with age. Second, values for $\infty \mathrm{X}_{13}^{a}$ are much higher for females than for males in the younger age groups but, this differential has narrowed considerably over time. This is clearly associated with the observation that the importance of longer spells for young males has risen more rapidly than for any other group over the period of our study.

The contribution of longer spells by group to total unemployment is perhaps a more interesting variable upon which to focus. The value for $\infty \mathrm{Y}_{13}^{a}$ has increased over the 3 years for most of the groups in our study. Of particular significance, are the 1983-4 values of 35.8 percent for young males and 50.0 percent for young females. If policies were devised which could prevent longer term unemployment from being experienced by men and women under 25 years of age, total male unemployment would be reduced by one third and total female unemployment by over a half. This finding, and those of the previous paragraph, represent insurmountable evidence against the proposition that youth unemployment is primarily short term in nature, and therefore not a problem of major policy concern. Clearly, youth unemployment is also concentrated in spells of long duration, and the longer spells of unemployment experienced by youth account for an unacceptable level of total unemployment.

\section{Conclusion}

In this paper we have extended the analysis of Brosnan and Hicks (1985) to encompass the duration of unemployment by age and sex. Examination of duration by age is of particular importance because of the often stated claim that the unemployment experience by younger workers is characterised by short spells and consequently fits neatly into the search explanation of unemployment. Our findings show that this is not a fair description of the youth experience in the New Zealand labour market. As is the case for other age groups, young people in New Zealand have, in recent years, witnessed a substantial increase in the average duration of a spell of unemployment. This increase has contributed significantly to rising levels of unemployment - particularly for males - and resulted in a situation in which spells of unemployment in excess 
Table 4: Percentage contribution of spells of specified duration to total unemployment and total spells: male and female.

\begin{tabular}{|c|c|c|c|c|c|c|c|c|c|c|}
\hline \multirow{4}{*}{ Sex and Year } & \multicolumn{2}{|c|}{ 0-4 Weeks } & \multicolumn{2}{|c|}{ 4-8 Weeks } & \multicolumn{2}{|c|}{$8-13$ Weeks } & \multicolumn{2}{|c|}{ 13-26 Weeks } & \multicolumn{2}{|c|}{26 Weeks Plus } \\
\hline & $\begin{array}{l}\text { Contribution } \\
\text { to spells }\end{array}$ & $\begin{array}{c}\text { Contribution } \\
\text { to unemploy- } \\
\text { ment }\end{array}$ & $\begin{array}{l}\text { Contribution } \\
\text { to spells }\end{array}$ & $\begin{array}{c}\text { Contribution } \\
\text { to unemploy- } \\
\text { ment }\end{array}$ & $\begin{array}{l}\text { Contribution } \\
\text { to spells }\end{array}$ & $\begin{array}{c}\text { Contribution } \\
\text { to unemploy- } \\
\text { ment }\end{array}$ & $\begin{array}{l}\text { Contribution } \\
\text { to spells }\end{array}$ & $\begin{array}{c}\text { Contribution } \\
\text { to unemploy- } \\
\text { ment }\end{array}$ & $\begin{array}{l}\text { Contribution } \\
\text { to spells }\end{array}$ & $\begin{array}{c}\text { Contribution } \\
\text { to unemploy- } \\
\text { ment }\end{array}$ \\
\hline & $4^{\mathrm{d}} 0$ & ${ }_{4} \mathrm{~V}_{0}$ & $4^{d_{4}}$ & ${ }_{4} V_{4}$ & $5^{\mathrm{d}} 8$ & ${ }_{5} \mathrm{~V}_{8}$ & $13^{\mathrm{d}_{13}}$ & ${ }_{13} \mathrm{~V}_{13}$ & $\infty \mathrm{d}_{26}$ & $\infty V_{26}$ \\
\hline & $\mathrm{I}_{0}$ & $\mathrm{~T}_{0}$ & $\mathrm{l}_{0}$ & $\mathrm{~T}_{0}$ & $\mathrm{l}_{0}$ & $\mathrm{~T}_{0}$ & $\mathrm{l}_{0}$ & $\mathrm{~T}_{0}$ & ${ }^{\mathrm{l}} 0$ & $\mathrm{~T}_{0}$ \\
\hline \multicolumn{11}{|l|}{$\begin{array}{l}\text { Males } \\
1981-2\end{array}$} \\
\hline $1981-2$ & 50.0 & 7.5 & 18.4 & 13.9 & 13.1 & 15.7 & 10.5 & 21.3 & 8.0 & 41.6 \\
\hline $1982-3$ & 42.3 & 2.6 & 18.9 & 11.9 & 14.4 & 14.1 & 12.3 & 20.7 & 12.1 & 50.7 \\
\hline $1983-4$ & 46.4 & 3.7 & 14.5 & 9.7 & 13.7 & 14.1 & 12.9 & 22.3 & 12.5 & 50.2 \\
\hline \multicolumn{11}{|l|}{ Females } \\
\hline $1981-2$ & 50.2 & 6.3 & 17.6 & 13.3 & 12.9 & 15.2 & 10.4 & 21.0 & 8.9 & 44.2 \\
\hline $1982-3$ & 51.4 & 5.5 & 15.9 & 11.7 & 12.3 & 14.1 & 10.5 & 20.6 & 9.9 & 48.1 \\
\hline $1983-4$ & 50.8 & 4.3 & 13.8 & 10.1 & 12.6 & 14.4 & 11.9 & 22.7 & 10.9 & 48.5 \\
\hline
\end{tabular}

Source: Computed from Department of Labour (various) 
of 13 weeks account for an excessively high amount of total unemployment.

The universality across groups of the concentration of unemployment in long spells throws severe doubt on the efficacy of job search theory as an explanation of the unemployment experience of any group in New Zealand. Such results further highlight the need for policy initiatives which will produce permanent, meaningful employment rather than just recycle the unemployed (O’Conner and Endres, 1985).

\section{References}

Baker, G M and Trivedi, P K (1982) Methods for estimating the duration of periods of unemployment Canberra, Australian National University (Working Papers in Economics and Econometrics No. 076).

Bowers, J K and Harkness, D (1979) Duration of unemployment by age and sex Economica 46: 239-260.

Brosnan, P and Hicks, J (1985) The duration of registered unemployment in New Zealand, 1967-1983: A life table approach New Zealand population review 11: 111-138.

Department of Labour (various) Monthly employment operations Wellington.

Department of Statistics (1981) New Zealand Census of Population and Dwellings 1981, Volume 4: Labour force Wellington.

Fowler, R F (1968) Duration of unemployment on the register of the wholly unemployed London, H.M.S.O.

Friedman, M (1968) The role of monetary policy American economic review 58: 1-17.

Hicks, J (1985) Discouraged workers and the hidden unemployed: Some theoretical and empirical considerations of the New Zealand experience Massey economic papers 3: 44-93.

Lippman, S A and McCall, J (1976) The economics of job search: A survey Economic inquiry 14, 155-189 (Part I) and 347-368 (Part II).

O'Conner, M P and Endres, A M (1985) On the review of employment subsidy programmes Auckland, Department of Economics, University of Auckland (Policy Discussion Papers No. 1).

Paterson, P R (1979) Turnover analysis of unemployment in Australia PhD Thesis, Australian National University.

Paterson, P R (1980) Why unemployment rates differ between groups: An analysis of unemployment inflows and duration for those on benefits Canberra, Australian National University, Centre for Economic Policy Research (Discussion Paper No. 17).

Phelps, E S (1968) Money wage dynamics and labour market equilibrium Journal of Political Economy 76: 678-711.

Trivedi, P K and Baker, G M (1982) Unemployment in Australia: Duration experience and recurrent spells Canberra, Australian National University Centre for Economic Policy Research (Discussion Paper No. 45). 